\title{
Seafood Consumption and Components for Health
}

\author{
Ryota Hosomi $^{1}$, Munehiro Yoshida ${ }^{2} \&$ Kenji Fukunaga ${ }^{2}$ \\ ${ }^{1}$ Division of Human Living Sciences, Tottori College, Kurayosi, Japan \\ ${ }^{2}$ Department of Life Science and Biotechnology, Faculty of Chemistry, Materials, and Bioengineering, Kansai \\ University, Suita, Japan \\ Correspondence: Kenji Fukunaga, Department of Life Science and Biotechnology, Faculty of Chemistry, \\ Materials, and Bioengineering, Kansai University, 3-3-35 Yamate-cho, Suita, Osaka 564-8680, Japan. Tel: \\ 81-663-68-0875. E-mail: fukunagk@kansai-u.ac.jp
}

Received: March 14, 2012 Accepted: March 27, 2012 Online Published: May 1, 2012

doi:10.5539/gjhs.v4n3p72 URL: http://dx.doi.org/10.5539/gjhs.v4n3p72

\begin{abstract}
In recent years, in developed countries and around the world, lifestyle-related diseases have become a serious problem. Numerous epidemiological studies and clinical trials have demonstrated that diet is one of the major factors that influence susceptibility to lifestyle-related diseases, especially the middle-senile state. Studies examining dietary habits have revealed the health benefits of seafood consumption. Seafood contains functional components that are not present in terrestrial organisms. These components include n-3-polyunsaturated fatty acids, such as eicosapentaenoic acid and docosahexsaenoic acid, which aid in the prevention of arteriosclerotic and thrombotic disease. In addition, seafood is a superior source of various nutrients, such as protein, amino acids, fiber, vitamins, and minerals. This review focuses on the components derived from seafood and examines the significant role they play in the maintenance and promotion of health.
\end{abstract}

Keywords: seafood consumption, fish, polyunsaturated fatty acid, health function, cardiovascular disease

\section{Introduction}

Lifestyle-related diseases, such as obesity, diabetes, hypertension, and hyperlipidemia, are widespread and increasing in developed countries. Metabolic syndrome includes a cluster of symptoms that are related to lifestyle diseases and is associated with an increased risk of type 2 diabetes, some types of cancers (Cerchietti et al., 2007), cardiovascular disease (CVD) (Hwu et al., 2008), and nonalcoholic fatty liver (Byrne 2010). Together with the rapid increase in the number of older people with lifestyle diseases, these have become serious national problems, both medically and financially. Increased dietary sugar and fat promotes obesity and diabetes (Linseisen et al., 2009; Cordain et al., 2005). Soft drink and fast-food consumption is influenced by several factors. Some of these factors include, but are not limited to, food availability, preferences, culture, age, and knowledge of nutrition and health. Reshaping the food environment is a promising new approach to lifestyle-related disease problems (Story et al., 2008; Glanz \& Yaroch 2004). Seafood is currently accepted as an essential food for humans (FAO 2010). Seafood is highly regarded for its abundance of high-quality proteins, n-3 polyunsaturated fatty acids (PUFAs), and other nutrients, such as minerals, trace elements, and vitamins (FAO 2010). These nutrients are essential for bodily functions and are beneficial to growth, the brain, and the nervous system; they also have anticancer properties (Liao \& Chao 2009). Seafood has helped alleviate food crises in many developing countries, providing a valuable supplement to a diverse and nutritious diet. In recent years, seafood consumption has gradually increased throughout the world (FAO 2010).

In Japan, the consumption of livestock food products, such as dairy products, meats, and their processed foods, have increased. This may lead to an increased incidence of CVD as a result of lifestyle-related diseases, such as hyperlipidemia, atherosclerosis, diabetes, and hypertension (Toshima 1994). Epidemiological and experimental reports have demonstrated a relationship between diet and incidence of CVD (Pereira et al., 2004; Osler et al., 2002). Therefore, dietary therapy is considered the first-choice treatment for arteriosclerotic disease and is recognized as being as important as medical treatment. Many researchers have demonstrated that seafood has nutritional characteristics that maintain and promote health (Mozaffarian \& Rimm 2006; Hu et al., 2002). In particular, the health benefits of seafood have principally been associated with high intakes of n-3 PUFAs, such as eicosapentaenoic acid (EPA) and docosahexaenoic acid (DHA) (Dyerberg et al., 1978). Fish oil contains abundant EPA and DHA and is sold as a functional food that can promote superior health. Many other bioactive 
components derived from seafood are also sold and are under development as functional foods (Harris 2004). Functional food is generally consumed as conventional food that forms a part of the daily diet. Functional food provides basic nutritional functions and reduces the risk of lifestyle-related diseases. Seafood and its derived bioactive components can help improve imbalanced dietary habits and prevent lifestyle-related diseases. In this review, we discuss fish consumption around the world and examine the evidence for the beneficial effects of the various components derived from seafood.

\section{Fish Consumption around the World and Consumer Demand for Seafood}

Over the past 40 years, fish and seafood consumption underwent a major change. In 2008, capture fisheries and aquaculture supplied more than 140 million tons of fish around the world (FAO 2010), approximately 115 million tons of which were for human consumption. Although the estimated per capita supply was approximately $10 \mathrm{~kg}$ in the 1960s, by 2008 it had increased to an average of $17 \mathrm{~kg}$ (FAO 2010). Adults require $60 \mathrm{~g}$ of protein each day; approximately $50 \%$ of this amount can be supplied by $150 \mathrm{~g}$ of fish. In 2007 , fish supplied $15.7 \%$ of the animal protein consumed and $6.1 \%$ of all protein consumed (FAO 2010). Over just a few years in China, the per capita fish supply increased rapidly and was approximately $26 \mathrm{~kg}$ in 2008. Asia accounted for two-thirds of human consumption; 36.9 million tons were consumed outside China and 33.6 million tons were consumed in China (FAO 2010). The average fish consumption per capita for North America, Central America and the Caribbean, South America, Oceania, and Europe was 24.1, 9.5, 8.4, 20.8, 24.5, and $20.8 \mathrm{~kg}$, respectively (FAO 2010). Fish and seafood consumption varied by more than 100 -fold between different areas of the world as well as between the inland and coastal regions of countries. Over the past 20 years, the food security of seafood has been improved due to technological developments in processing, distribution, transportation, and storage. These improvements realized cost saving and enhanced safety and quality. Moreover, the development of large-scale, long-distance refrigerated transport and faster shipments revitalized international trade and resulted in the consumption of a wider variety of species and fresh fish. In developed countries, consumers demanded high quality, convenience, reliability, and safety. Consumers in these countries also seek out food that has health-promoting qualities.

\section{Health Effects of Seafood Consumption}

Epidemiological evidence gathered from Greenland Inuit and Japanese fishing villages has demonstrated that the intake of marine animal products is effective in the prevention of CVD (Kagawa et al., 1982; Bang et al., 1980). Many other studies from a variety of countries have also reported that seafood consumption helps protect against lifestyle-related diseases. Numerous epidemiological studies have examined the relationship between dietary marine products and CVD (Guallar et al., 2002; Krauss et al., 2000; von Schacky et al., 1999; Singh et al., 1997). In one report, individuals who consumed fatty fish had a $34 \%$ reduction in CVD in a three-cohort study (Oomen et al., 2000), and $35 \mathrm{~g}$ /day of fish consumption resulted in decreased CVD mortality (Daviglus et al., 1997).

A meta-analysis revealed that individuals who consumed fish once a week had a $15 \%$ lower risk of CVD mortality compared with individuals who consumed no fish (He et al., 2004). The intake of lean and fatty fish in a sample British population was associated with a reduction in diabetes risk in the epidemiological data from the European Prospective Investigation of Cancer (EPIC)-Norfolk cohort study (Patel et al., 2009). One ecological study reported that high frequency fish and seafood consumption decreased the risk of type 2 diabetes in populations with an overweight group (Nkondjock \& Receveur, 2003). Sufficient seafood consumption in childhood has been demonstrated to help ensure good fetal neuron development and infant and child cognitive and visual development (Ryan et al., 2010; Carlson, 2009); however, whether or not these positive effects continue into adulthood has not been confirmed. The medical benefits of fish consumption have also been examined as they pertain to inflammatory diseases (Gopinath et al., 2011; Rosell et al., 2009), certain cancers (Szymanski et al., 2010; Dewailly et al., 2003; Zhang et al., 1999), dementia (Cederholm \& Palmblad, 2010; Robinson et al., 2010), and psychological status (Appleton et al., 2010).

\section{The Health Benefits of Bioactive Components Derived from Seafood}

The health benefits of seafood and fish oil consumption according to an epidemiological survey of Greenland Inuit by Dyerberg et al are very interesting (Dyerberg et al., 1978). Although the Inuit have a very high-fat diet, the prevalence of ischemic disease is very low in the population. This report received worldwide attention, and studies related to the health functionality of marine products were widely conducted as a result. Many marine organisms inhabit complex environments that are exposed to extreme conditions and, as a result of adapting to the changing environment, they produce a wide range of secondary (biologically active) metabolites. Marine organisms have many bioactive components, such as n-3 PUFAs, protein, fiber, taurine, sterol, and pigments; they also contain unique components that are not present in terrestrial organisms. Nutrients and other bioactive 
components derived from fish and marine organisms may become functional food ingredients that have medical characteristics and provide health benefits.

\section{1 n-3 PUFA}

The various beneficial effects of seafood have primary been attributed to n-3 PUFAs such as EPA and DHA. Marine organisms have been identified as the only foods that contain a naturally high amount of these fatty acids. This arises from the fact that marine phytoplankton has a high ratio of EPA and DHA, and thus these fatty acids are accumulated in the food chain. The total content of EPA and DHA in fish varies depending on the type of fish and their habitat. The proportion of n-3 PUFAs in fish muscle is higher in fatty fish, such as mackerel, herring, and salmon, than in lean fish, such as cod, haddock, and halibut. In addition, shellfish, such as crab, shrimp, and lobster, have low levels of n-3 PUFAs (Shahidi, 2011).

The metabolites of EPA are the most well known and include eicosanoids, such as the 3-series prostaglandins, prostacyclins, and thromboxanes, and the 5-series leukotrienes (Calder, 1998). The eicosanoids derived from EPA are less active than the pro-inflammatory and pro-thrombotic eicosanoids derived from arachidonic acid. The n-3 and n- 6 fatty acids compete for conversion into these important metabolites. In fact, tissue n- $6 / n-3$ levels are largely determined by dietary intake levels (Lands et al., 1992).

Daily intake of n-3 PUFAs such as EPA and DHA reduce the rate of incidence and death from CVD. For example, in the GISSI-Prevention study (Marchioli et al., 2002), more than 2,800 Italians who were heart attack survivors consumed $850 \mathrm{mg}$ of purified EPA/DHA in capsule form for 3.5 years. The results revealed that, compared with a similar number of patients who did not consume the EPA/DHA capsules, there was a $20 \%$ reduction in the rate of any-cause death and a $45 \%$ reduction in the rate of death from CVD. n-3 PUFAs supplementation therapy continues to demonstrate considerable promise in the primary and secondary prevention of CVD (Lavie et al., 2009).

For preventing general heart disease, the American Heart Association (AHA) recommends approximately $1 \mathrm{~g}$ of EPA/DHA per day for coronary heart disease patients (Kris-Etherton et al., 2002). For healthy people, the AHA recommends consuming fatty fish at least twice a week (30-40 g per day), or approximately $500 \mathrm{mg}$ of EPA/DHA per day. Hypertriglyceridemia patients are advised to ingest 2 to $4 \mathrm{~g}$ of EPA/DHA per day (Lichtenstein et al., 2006). Further, the consumption of 3 to $20 \mathrm{~g}$ or more of EPA/DHA has been examined in terms of the dietary effects on serum triglycerides (TG), blood pressure, platelet aggregation activity, endothelial function, blood vessel flexibility, and inflammation (Kris-Etherton et al., 2003). A previous study found that treatment with $1.5 \mathrm{~g}$ of EPA/DHA per day appeared to improve carotid artery plaques stability (Thies et al., 2003). n-3 PUFAs intake has also been associated with beneficial effects related to obesity, insulin sensitivity, and the reduction of inflammatory markers (Ramel et al., 2010; Rudkowska 2010; Ramel et al., 2008; Nettleton \& Katz 2005). In a murine model of obesity and insulin resistance, dietary n-3 PUFAs were incorporated in the cell membrane phospholipids; they enhanced the membrane fluidity and the expression, affinity, and some insulin receptors (Das 1999) as well as glucose transporter-4 protein levels in adipose tissue (Peyron-Caso et al., 2002), thereby improving insulin sensitivity.

In addition, n-3 PUFAs have beneficial effects on adipose tissue in obese individuals through reduced body fat mass and stimulated lipid oxidation (Couet et al., 1997), improvement in body weight and satiety regulation (Abete et al., 2010), amelioration of the cytokine profile, including leptin and adiponectin (Abete et al., 2010), and a reduction of inflammation (Das 2005), rheumatoid arthritis (Volker et al., 2000), systemic lupus erythematosus (Walton et al., 1991), Crohn's disease (Belluzzi et al., 1996), ulcerative colitis (Stenson et al., 1992), and immunoglobulin A nephropathy (Donadio et al., 1994). There is also an increasing amount of evidence that suggests that diets containing fish and/or EPA/DHA may protect against the development of Alzheimer's disease (Morris et al., 2003) and prostate cancer (Terry et al., 2001).

\subsection{Phospholipids}

Although the majority of fat in seafood is TG, approximately $10 \%$ consists of phospholipids (PLs). Numerous studies using animal models have suggested that dietary PLs may be of benefit to human health. For example, phosphatidylcholine, which is a major component of dietary PLs, can decrease blood total lipids (Mastellone et al., 2000) and improve brain function (Chung et al., 1995). Phosphatidylethanolamine and phosphatidylserine can also decrease blood cholesterol (Imaizumi et al., 1983) and improve brain function (Mc Daniel et al., 2003).

As for PLs derived from seafood, EPA and DHA, which have excellent potential as functional food ingredients, are abundant. Dosing with PL-containing n-3 PUFAs resulted in a higher PUFAs content in plasma than dosing with TG-containing n-3 PUFAs (Wijendran et al., 2002; Galli et al., 1992). For these reasons, it is clear that PL-containing n-3 PUFAs are more effective than TG-containing n-3 PUFAs when administered. There have 
been several human studies that have investigated the beneficial effects of supplementation with dietary krill oil, which has PL-containing n-3 PUFAs rather than TG-containing n-3 PUFAs. Results indicate that krill oil supplementation was well tolerated and caused desirable increases in plasma and cell membrane EPA and DHA levels (Wang et al., 2011; Maki et al., 2009). Furthermore, PL-containing n-3 PUFAs are beneficial in that they can help alleviate obesity-related disorders (Shirouchi et al., 2007) and act as antiinflammatory (Ikemoto et al., 2001), antioxidant (Hiratsuka et al., 2008), and antitumor agents (Hosokawa et al., 2001) in animal experiments. Previous studies have suggested that PL-containing n-3 PUFAs derived from squid mantle muscle decreased serum and liver TG and cholesterol levels compared with that induced by soybean PL- or TG-containing n-3 PUFAs (Hosomi et al., 2010a). Although, research in this field is still in the initial stage, it has been receiving increasing attention as a result of the realization that PL-containing n-3 PUFAs may provide vital outcomes and facilitate progress in the design of beneficial clinical therapies for humans.

\subsection{Protein, Peptide, and Non-Protein Nitrogen Compounds}

It is generally accepted that seafood is a high-quality source of protein and that seafood consumption provides health benefits to growing children, adolescents, and the elderly. Normal dietary habits include fish oil as well as whole fish, which provide many additional nutrients. Dietary n-3 PUFAs decrease serum TG, although they do not lower serum cholesterol (Balk et al., 2006). Therefore, there is a possibility that the health function of fish-based foods is not solely related to EPA and DHA. There is a great deal of research that is focused on the efficacy of EPA and DHA in seafood for human health, whereas there is almost none related to the health effects of proteins. As nutrient components of seafood, the beneficial effect of proteins may have been masked by EPA and DHA in seafood intake intervention studies. Fish protein, which is a major micronutrient in fish, plays an important role in human nutrition worldwide (FAO 2010) and has been used as a main ingredient in processed seafood, such as kamaboko (Japanese fish paste) and fish sausage. Seafood proteins possess excellent amino acid scores and digestibility characteristics. These constitute approximately 10 to $25 \%$ of seafoods and can be classified as sarcoplasmic, myobibrillar, and stroma types. In general, amino acid compositions and the bioavailability of animal protein are more suitable than plant protein, and the protein quality of most fish proteins may be equal to that of an ideal protein such as lactalbumin, and exceed that of terrestrial meat (Friedman 1996).

Another aspect of the role of fish proteins in human health pertains to their possible effects on lipid metabolism. In this context, our group and other investigators have demonstrated that fish proteins affect serum cholesterol levels in experimental animals (Hosomi et al., 2009; Wergedahl et al., 2009; Shukla et al., 2006; Zhang \& Beynen 1993). A previous study suggested that dietary fish protein decreased serum cholesterol through the inhibition of cholesterol and bile acid absorption and the enhancement of cholesterol catabolism in the liver (Hosomi et al., 2009). In addition, dietary fish protein also has beneficial effects, such as antihypertensive (Boukortt et al., 2004), stimulation of fibrinolysis (Murata et al., 2004), and antiobesity properties (Oishi \& Dohmoto, 2009).

In human studies, compared with other animal proteins, dietary cod proteins decreased the highly sensitive C-reactive proteins concentration in serum (Ouellet et al., 2008) and improved insulin sensitivity in insulin-resistant individuals (Ouellet et al., 2007). Recently, the large Nurse's Health Study, which is a prospective study following more than 84,000 women aged 30 to 55 years over a 26 -year period, suggested that increasing the intake of fish as a major dietary protein source provided a significant CVD reduction risk (Bernstein et al., 2010). Thus far, the health functions of various types of fish tissue besides muscle were examined. Although the testes and ovaries are edible parts, only information related to their high cholesterol and nucleic acids content is available. Protamine, which is abundant in fish testes, has been widely used as a pharmaceutical product as an antidote to heparin. It maintains its antihyperglycemic effects together with insulin, and is a natural food preservative. Protamine strongly inhibited the hydrolysis of trioleoylglycerol emulsion using phosphatidylcholine (Tsujita et al., 1996), suppressed lipid absorption in the oral tolerance test in humans (Hoshino et al., 2008), and also suppressed the increase of body mass through the inhibition of fat absorption in small intestine (Duarte-Vázquez et al., 2009). Furthermore, dietary protamine resulted in decreased serum and liver cholesterol levels through the suppression of cholesterol and bile acid absorption, and enhanced the cholesterol secretion from the liver into bile in rats (Hosomi et al., 2010b). In recent years, many people have become interested in the health promotion properties of bioactive peptides prepared from seafood protein.

In a group administered the valyl-tyrosine peptide, which was derived from sardine muscle hydrolysate by alkaline protease, systolic and diastolic blood pressure was reduced by 9.3 and $5.2 \mathrm{~mm} \mathrm{Hg}$, respectively, in a four-week double-blind placebo controlled trial (Kawasaki et al., 2000). In addition, the inhibition of lipid peroxidation by a marine bioactive peptide, isolated from jumbo squid, was determined using a linoleic acid 
model system, and its activity was much higher than $\alpha$-tocopherol and close to that of butylated hydroxytoluene (Mendis et al., 2005). Marine bioactive peptides also have beneficial effects such as immunomodulating (Duarte et al., 2006), hypocholesterolemia (Wergedahl et al., 2004), and antimicrobial effects (Tincu \& Taylor 2004) in animal and in vitro studies. The various health functions of protein and peptides derived from seafood have been clarified by researchers using animal and human studies. Several long-term human studies have been undertaken to evaluate the health effects of marine proteins. In the future, the assessment of the health benefits of marine protein in humans needs to be assessed in long-term clinical trials.

Non-protein nitrogen (NPR) compounds are also present, to various extents, depending on the species. The dark muscles of fish generally contain a higher amount of NPR compounds than the light muscles. NPR compounds in muscle tissues are composed of free amino acids, amines, nucleotides, guanidine and their breakdown products, urea, and ammonium salts (Shahidi, 1998). The contribution of NPR compounds to the taste of seafood is important.

\subsection{Taurine}

With the exception of free amino acid, taurine (2-aminoethanesulfonic acid) is present in nearly all tissues and is particularly abundant in the heart, blood, retina, and developing brain (Wójcik et al., 2010). Taurine synthetic activity in humans is weaker than that in guinea-pigs and rats, and dietary dependence on taurine is high. Hence, taurine is a nonessential but conditionally essential amino acid in the human body (Huxtable, 1992). Taurine has many important roles in several essential biological processes, such as calcium modulation, bile acid conjugation, antioxidation, membrane stabilization, and immunity (Schuller-Levis \& Park, 2004; Huxtable 2000; Huxtable 1992). Humans consume taurine largely through seafood, which contains high amounts of taurine compared to meat (Tsuji \& Yano, 1984). In particularly, taurine is particularly abundant in some marine invertebrates: oyster tissue has more than $1 / 100 \mathrm{~g}$ the taurine content, whereas the taurine content in terrestrial plants is low or absent (Kataoka \& Onishi, 1986). Taurine has beneficial antihypertensive (Schaffer et al., 2010; Harada et al., 2004), antihypercholesterolemic (Matsushima et al., 2003), and antiinflammatory effects on lifestyle-related diseases (Jerlich et al., 2000). Furthermore, human intervention studies have revealed that the administration of taurine and n-3 PUFAs has hypolipidemic and antiatherogenic effects compared with n-3 PUFAs supplementation alone (Elvevoll et al., 2008). In non-diabetic obese human subjects, $3 \mathrm{~g} /$ day taurine supplementation for 7 weeks reduced serum TG, the atherogenic index, and body weight compared to a placebo group (Zhang et al., 2004). These findings suggest that the consumption of a sufficient quantity of taurine may be important in reducing the risk of lifestyle-related diseases. However, further clinical trials are required to confirm the health promotion mechanism of taurine.

\subsection{Fiber}

In general, muscle-based seafood contains very little carbohydrate and fiber. However, edible seaweed contains a lot of dietary fiber $(25-75 \%$ dry weight), and water-soluble fiber constitutes approximately 50 to $85 \%$ (Jimenez-Escrig \& Sanchez-Muniz, 2000). On the basis of their pigmentation, seaweeds are classified into three main groups. Brown seaweeds are predominantly brown due to fucoxanthin and have primary polysaccharides such as fucans, cellulose, alginates, and laminarins (Goni et al., 2002; Haugan \& Liaaenjensen, 1994). Green seaweeds are green due to the presence of chlorophyll and ulvan, which is a major polysaccharide component (Robic et al., 2009). Red seaweeds have phycoerythrin and phycocyanin as their principal pigments; they also contain agars and carrageenans as the primary polysaccharides (McHugh 2003). In animal studies, polysaccharides extracted from various edible seaweeds have been found to reduce total cholesterol, low-density lipoprotein (LDL)-cholesterol, and TG in plasma (Amano et al., 2005; Pengzhan et al., 2003). The hypocholesterolemic effect of polysaccharides may be due to an augmented interfering with micelle formation and lipid absorption in the small intestine or an increased excretion of neutral sterols and biliary acids in feces. In addition, sulfated polysaccharides, such as fucoidan and carrageenans, are recognized to possess a number of biological activities, including anticoagulant (Matsubara et al., 2000), antiviral (Artan et al., 2008), antioxidant (Heo et al., 2005), and antiinflammatory (Kim et al., 2009) effects that may have relevance in functional foods, cosmetics, and pharmaceutical applications (d'Ayala et al., 2008; Guo et al., 1998). While a substantial number of studies has been conducted to date both in vitro and in vivo, few studies have been conducted on human subjects. Further study related to the fiber in seaweed should aim to examine the health benefits in human subjects.

\subsection{Phytosterols}

The structure of phytosterols is also similar to cholesterol, with only minor differences in the relative position of ethyl and methyl groups. Phytosterols are common ingredients in plants, and the principal forms are $\beta$-sitosterols, 
stigmasterol, and campesterol. The forms of phytosterols in marine invertebrates include free sterols, stanols, and sterol ester (Kanazawa 2001). Phytosterols are often used to develop health food, including low-fat and fat-free yogurt, milk, juices, spreads, cereals, and bread (Demonty et al., 2009). Clinical trials have consistently shown that an intake of 2 to $3 \mathrm{~g} /$ day of phytosterols is associated with a significant lowering (between 4.1 and $15 \%$ ) of blood LDL-cholesterol (Malinowski \& Gehret 2010; de Jong et al., 2008; Patch et al., 2005; Thompson \& Grundy 2005). The hypocholesterolemic effects associated with an intake of certain edible microalgae have been demonstrated to be caused by phytosterols, and microalgae have been launched as industrial producers of phytosterols (Plaza et al., 2009; Rasmussen et al., 2009). The lipid-lowering mechanism of phytosterols is thought to occur when phytosterols compete with the absorption of cholesterol by binding to micelles in the intestine (Jones et al., 2000). Their presence in the intestine thus adversely affects the stabilization of cholesterol into micelles, thereby decreasing cholesterol absorption. Another aspect of phytosterols is that they enhance the enterocyte ATP-binding cassette (ABC) G5 and ABCG8 proteins, which act to excrete cholesterol into the intestinal lumen and expression (Marangoni \& Poli 2010; Patch et al., 2006). Phytosterols have also been reported to be responsible for other biochemical properties, including antiinflammatory (Houweling et al., 2009), antioxidant (Mannarino et al., 2009), and anticancer effects (Bouic 2001). Few studies have examined the relationship between high-dose phytosterols and the reduction in fat-soluble vitamins, antioxidants, and carotenoids (Musa-Veloso et al., 2011; Katan et al., 2003). Further research is needed to gain more insight into the security of phytosterols as food and functional supplements in the human body.

\subsection{Carotenoids}

Carotenoids are fat-soluble and they have brilliant yellow and orange pigments. They act to transform light energy into chemical energy and antioxidants that inactivate the harmful reactive oxygen species of photosynthetic organisms, plankton, and fungi (Lesser, 2006). One of the most important biological functions of carotenoids such as $\beta$-carotene in the human body is their ability to form vitamin A (García-González et al., 2005). However, other carotenoids, such as astaxanthin, lycopene, and fucoxanthin, do not form vitamin A. Recently, the astaxanthin and fucoxanthin derived from seafood have been reported on for a wide range of commercial applications based on their biological properties. Astaxanthin is a xanthophyll carotenoid that is contained in salmonid fish, lobsters, and marine crustaceans. Astaxanthin is considered to have health-promoting effects because astaxanthin oral supplementation in healthy human volunteers caused significant reductions in biomarkers of oxidative stress, inflammation, and hyperlipidemia (Cicero et al., 2007; Karppi et al., 2007; Iwamoto et al., 2000). Non-obsese individuals who consumed astaxanthin for 12 weeks had decreased TG and increased high-density lipoprotein (HDL) cholesterol, which is related to an increase in the adiponectin level (Yoshida et al., 2010). A limited number of clinical studies in humans have been conducted to test the safety of the consumption of astaxanthin. Fucoxanthin is an orange-colored carotenoid found in edible brown seaweeds, such as Undaria pinnatif, Hijiki afusiformis, Laminaria japonica, and Sargassum fulvelum (Maeda et al., 2007). Fucoxanthin prevents the growth of fat tissue, reduces abdominal fat, and reduces the risk of stroke, inflammation, and various cancers (Maeda et al., 2008; Ikeda et al., 2003). Although the beneficial functions of fucoxanthin are beginning to be examined, fucoxanthin administration is known to markedly elevate plasma HDL-cholesterol and total cholesterol levels (Woo et al., 2010; Kadekaru et al., 2008). Before fucoxanthin is used as a functional supplement, further study is required to determine its safety.

\section{Risk associated with Fish Consumption}

The health benefits related to the reduction in risk of CVD have triggered the mass consumption of fish (FAO 2010). Fish consumption, however, also carries certain risks associated with exposure to environmental toxicants. For instance, the only exposure to methylmercury is through edible marine products. Free mercury easily metabolizes methylmercury by microorganisms and is accumulated in the fish at the top of the food chain. Methylmercury exposure affects the highly sensitive nervous system. The developing fetal and infant nervous systems are also highly sensitive to methylmercury. Methylmercury induces central nervous system damage that depends on the amount ingested (Clarkson et al., 2003; Yoshizawa et al., 2002).

Fish consumption recommendations for pregnant women and children are accompanied by warnings regarding how much and what kind of fish should be consumed (FDA 2004). Further, the dioxins and polychlorinated biphenyls contained in seafood have caused concerns related to the health effects of seafood consumption (Arisawa et al., 2005; Arisawa et al., 2003). The balancing of the health benefits and risks of fish intake is an important problem (He, 2009). Some researchers have reported that the consumption of seafood provides benefits that outweigh the risks, except for shark, swordfish, and edible animals and plants from areas with high levels of environmental contaminants (Dewailly et al., 2007; Yaktine \& Nesheim 2007; Yoshizawa et al., 2002). 


\section{Conclusion}

People have come to realize the importance of seafood in our diet. Numerous studies have proved that some of the best sources of excellent fats, protein, vitamins, and minerals that promote health can be found in seafood. It is unfortunate that it took so many years for the health benefits of seafood to be realized. In the future, an increase in lifestyle-related diseases, the majority of which are a result of dietary habits, is expected in both developed and developing countries (Daar et al., 2007). There is evidence that increased consumption of seafood and bioactive components derived from fish, shellfish, and seaweed could have a positive impact on the health of people around the world. Thus, the role of seafood in the maintenance and enhancement of health may grow stronger, given the problem of lifestyle-related disease and the local food environment. To sum, it is of paramount importance to promote the consumption of seafood and a reduction in high-sugar and high-fat food, including fast food and soft drinks (sugar, in particular), saturated fatty acids, and n-6 PUFAs, which is currently excessive.

\section{References}

Abete, I., Astrup, A., Martínez, J. A., et al. (2010). Obesity and the metabolic syndrome: role of different dietary macronutrient distribution patterns and specific nutritional components on weight loss and maintenance. Nutrition Review, 68(4), 214-231. http://dx.doi.org/10.1111/j.1753-4887.2010.00280.x

Amano, H., Kakinuma, M., Coury, D., et al. (2005). Effect of a seaweed mixture on serum lipid level and platelet aggregation in rats. Fisheries Science, 71(5), 1160-1166. http://dx.doi.org/10.1111/j.1444-2906.2005.01076.x

American Heart Association Nutrition Committee, Lichtenstein, A. H., Appel, L. J., Brands, M., et al. (2006). Diet and lifestyle recommendations revision 2006: a scientific statement from the American Heart Association Nutrition Committee. Circulation, 114(1), 82-96. http://dx.doi.org/10.1161/CIRCULATIONA HA.106.176158

Appleton, K. M., Rogers, P. J., \& Ness, A. R. (2010). Updated systematic review and meta-analysis of the effects of n-3 long-chain polyunsaturated fatty acids on depressed mood. The American Journal of Clinical Nutrition, 91(3), 757-70. http://dx.doi.org/10.1161/10.3945/ajcn.2009.28313

Arisawa, K., Takeda, H., \& Mikasa, H. (2005). Background exposure to PCDDs/PCDFs/PCBs and its potential health effects: a review of epidemiologic studies. The Journal of Medical Investigation, 52(1-2), 10-21. http://dx.doi.org/10.2152/jmi.52.10

Arisawa, K., Matsumura, T., Tohyama, C., et al. (2003). Fish intake, plasma omega-3 polyunsaturated fatty acids, and polychlorinated dibenzo-p-dioxins/polychlorinated dibenzo-furans and co-planar polychlorinated biphenyls in the blood of the Japanese population. International Archives of Occupational and Environmental Health, 76(3), 205-15. http://dx.doi.org/10.1007/s00420-002-0400-y

Artan, M., Li, Y., Karadeniz, F., et al. (2008). Anti-HIV-1 activity of phloroglucinol derivative, 6,6'-bieckol, from Ecklonia cava. Bioorganic \& Medicinal Chemistry, 16(17), 7921-6. http://dx.doi.org/10.1016/j.bmc.2008. 07.078

Balk, E. M., Lichtenstein, A. H., Chung, M., et al. (2006). Effects of omega-3 fatty acids on serum markers of cardiovascular disease risk: a systematic review. Atherosclerosis. 189(1), 19-30. $\mathrm{http}: / / \mathrm{dx}$.doi.org/10.1016/j.atherosclerosis.2006.02.012

Bang, H. O., Dyerberg, J., \& Sinclair, H. M. (1980). The composition of the Eskimo food in northwestern Greenland. The American Journal of Clinical Nutrition. 33(12), 2657-61.

Belluzzi, A., Brignola, C., Campieri, M., et al. (1996). Effect of an enteric-coated fish-oil preparation on relapses in Crohn's disease. The New England Journal of Medicine. 334(24), 1557-60.

Bernstein, A. M., Sun, Q., Hu, F. B., et al. (2010). Major dietary protein sources and risk of coronary heart disease in women. Circulation, 122(9), 876-83. http://dx.doi.org/10.1161/CIRCULATIONAHA.109.915165

Bouic, P. J. (2001). The role of phytosterols and phytosterolins in immune modulation: a review of the past 10 years. Current Opinion in Clinical Nutrition \& Metabolic Care, 4(6), 471-5. http://dx.doi.org/10.1097/0007 5197-200111000-00001

Boukortt, F. O., Girard, A., Prost, J. L., et al. (2004). Fish protein improves the total antioxidant status of streptozotocin-induced diabetes in spontaneously hypertensive rat. Medical Science Monitor. 10(11), BR397-404.

Byrne, C. D. (2010). Fatty liver: role of inflammation and fatty acid nutrition. Prostaglandins, Leukotrienes and 
Essential Fatty Acids, 82(4-6), 265-71. http://dx.doi.org/10.1016/j.plefa.2010.02.012

Calder, P. C. (1998). Dietary fatty acids and the immune system. Nutrition Review, 56(1 Pt 2), S70-83. http://dx.doi.org/10.1111/j.1753-4887.1998.tb01648.x

Carlson, S. E. (2009). Docosahexaenoic acid supplementation in pregnancy and lactation. The American Journal of Clinical Nutrition, 89(2), 678S-684S. http://dx.doi.org/10.3945/ajcn.2008.26811E

Cederholm, T., \& Palmblad, J. (2010). Are omega-3 fatty acids options for prevention and treatment of cognitive decline and dementia? Current Opinion in Clinical Nutrition \& Metabolic Care, 13(2), 150-5. http://dx.doi.org/10.1097/MCO.0b013e328335c40b

Cerchietti, L. C., Navigante, A. H., \& Castro, M. A. (2007). Effects of eicosapentaenoic and docosahexaenoic n-3 fatty acids from fish oil and preferential Cox-2 inhibition on systemic syndromes in patients with advanced lung cancer. Nutrition and Cancer. 59(1), 4-20. http://dx.doi.org/10.1080/01635580701365068

Chung, S. Y., Moriyama, T., Uezu, E., et al. (1995). Administration of phosphatidylcholine increases brain acetylcholine concentration and improves memory in mice with dementia. Journal of Nutrition, 125(6), 1484-9.

Cicero, A. F., Rovati, L. C., \& Setnikar, I. (2007). Eulipidemic effects of berberine administered alone or in combination with other natural cholesterol-lowering agents. A single-blind clinical investigation. Arzneimittel Forschung, 57(1), 26-30.

Clarkson, T. W., Magos, L., \& Myers, G. J. (2003). The toxicology of mercury—current exposures and clinical manifestations. The New England Journal of Medicine, 349(18), 1731-7.

Cordain, L., Eaton, S. B., Sebastian, A., et al. (2005). Origins and evolution of the Western diet: health implications for the 21st century. The American Journal of Clinical Nutrition, 81(2), 341-54.

Couet, C., Delarue, J., Ritz, P., et al. (1997). Effect of dietary fish oil on body fat mass and basal fat oxidation in healthy adults. International Journal of Obesity and Related Metabolic Disorders, 21(8), 637-43.

d'Ayala, G. G., Malinconico, M., \& Laurienzo, P. (2008). Marine derived polysaccharides for biomedical applications: chemical modification approaches. Molecules. 13(9), 2069-106. http://dx.doi.org/10.3390/ molecules13092069

Daar, A. S., Singer, P. A., Persad, D. L., et al. (2007). Grand challenges in chronic non-communicable diseases. Nature, 450(7169), 494-6. http://dx.doi.org/10.1038/450494a

Das, U. N. (1999). GLUT-4, tumor necrosis factor, essential fatty acids and daf-genes and their role in glucose homeostasis, insulin resistance, non-insulin dependent diabetes mellitus, and longevity. Journal of the Association of Physicians of India, 47(4), 431-5.

Das, U. N. (2005). A defect in the activity of Delta6 and Delta5 desaturases may be a factor predisposing to the development of insulin resistance syndrome. Prostaglandins, Leukotrienes and Essential Fatty Acids, 72(5), 343-50.

Daviglus, M. L., Stamler, J., Orencia, A. J., et al. (1997). Fish consumption and the 30-year risk of fatal myocardial infarction. The New England Journal of Medicine, 336(15), 1046-53.

de Jong, A., Plat, J., Lütjohann, D., et al. (2009). Effects of long-term plant sterol or stanol ester consumption on lipid and lipoprotein metabolism in subjects on statin treatment. British Journal of Nutrition, 100, 937-41. http://dx.doi.org/10.1017/S0007114508966113

Demonty, I., Ras, R. T., van der Knaap, H. C., et al. (2009). Continuous dose-response relationship of the LDL-cholesterol-lowering effect of phytosterol intake. Journal of Nutrition, 139(2), 271-84. http://dx.doi.org/10.3945/jn.108.095125

Dewailly, E., Ayotte, P., Lucas, M., et al. (2007). Risk and benefits from consuming salmon and trout: a Canadian perspective. Food and Chemical Toxicology, 45(8), 1343-8. http://dx.doi.org/10.1016/j.fct.2007. 01.010

Dewailly, E., Mulvad, G., Sloth Pedersen, H., et al. (2003). Inuit are protected against prostate cancer. Cancer Epidemiology, Biomarkers \& Prevention, 12(9), 926-7.

Donadio, J. V. Jr., Bergstralh, E. J., Offord, K. P., et al. (1994). A controlled trial of fish oil in IgA nephropathy. Mayo Nephrology Collaborative Group. The New England Journal of Medicine, 331(18), 1194-9.

Duarte-Vázquez, M. A., García-Padilla, S., Olvera-Ochoa, L., et al. (2009). Effect of protamine in obesity 
induced by high-fat diets in rats. International Journal of Obesity, 33(6), 687-92. http://dx.doi.org/10.1038/ijo.2009.78

Duarte, J., Vinderola, G., Ritz, B., et al. (2006). Immunomodulating capacity of commercial fish protein hydrolysate for diet supplementation. Immunobiology, 211(5), 341-50. http://dx.doi.org/10.1016/j.imbio. 2005.12.002

Dyerberg, J., Bang, H. O., Stoffersen, E., et al. (1978). Eicosapentaenoic acid and prevention of thrombosis and atherosclerosis. Lancet, 2(8081), 117-9. http://dx.doi.org/10.1016/S0140-6736(78)91505-2

Elvevoll, E. O., Eilertsen, K. E., Brox, J., et al. (2008). Seafood diets: hypolipidemic and antiatherogenic effects of taurine and n-3 fatty acids. Atherosclerosis, 200(2), 396-402. http://dx.doi.org/10.1016/j.atherosclerosis. 2007.12.021

Food and Agriculture Organization of the United Nations, World Health Organization. (2010). Report oh the Joint FAO/WHO Expert Consultation on the Risks and Benefits of Fish Consumption. FAO Fisheries and Aquaculture Report No. 978.

Friedman, M. (1996). Nutritional Value of Proteins from Different Food Sources. A Review. Journal of Agricultural and Food Chemistry, 44(1), 6-29. http://dx.doi.org/10.1021/j99400167

Galli, C., Sirtori, C. R., Mosconi, C., et al. (1992). Prolonged retention of doubly labeled phosphatidylcholine in human plasma and erythrocytes after oral administration. Lipids, 27(12), 1005-12. http://dx.doi.org/10.1007/BF02535580

García-González, M., Moreno, J., Manzano, J. C., et al. (2005). Production of Dunaliellasalina biomass rich in 9-cis-beta-carotene and lutein in a closed tubular photobioreactor. Journal of Biotechnology, 115(1), 81-90. http://dx.doi.org/10.1016/j.jbiotec.2004.07.010

Glanz, K., \&Yaroch, A. L. (2004). Strategies for increasing fruit and vegetable intake in grocery stores and communities: policy, pricing, and environmental change. Preventive Medicine, 39(Suppl 2), S75-80. http://dx.doi.org/10.1016/j.ypmed.2004.01.004

Goñi, I., Valdivieso, L., \& Gudiel-Urbano, M. (2002). Capacity of edible seaweeds to modify in vitro starch digestibility of wheat bread. Nahrung, 46(1), 18-20. http://dx.doi.org/10.1002/1521-3803(20020101)46:1

$<18::$ AID-FOOD18>3.0.CO;2-C

Gopinath, B., Buyken, A. E., Flood, V. M., et al. (2011). Consumption of polyunsaturated fatty acids, fish, and nuts and risk of inflammatory disease mortality. The American Journal of Clinical Nutrition, 93(5), 1073-9. http://dx.doi.org/10.3945/ajen.110.009977

Guallar, E., Sanz-Gallardo, M. I., van't Veer, P., et al. (2002). Mercury, fish oils, and the risk of myocardial infarction. The New England Journal of Medicine, 347(22), 1747-54.

Guo, J. H., Skinner, G. W., Harcum, W. W., et al. (1998). Pharmaceutical applications of naturally occurring water-soluble polymers. Pharmaceutical Science \& Technology Today, 1(6), 254-61. http://dx.doi.org/10. 1016/S1461-5347(98)00072-8

Harada, H., Tsujino, T., Watari, Y., et al. (2004). Oral taurine supplementation prevents fructose-induced hypertension in rats. Heart Vessels, 19(3), 132-6.

Harris, W. S. (2004). Fish oil supplementation: evidence for health benefits. Cleveland Clinic Journal of Medicine, 71(3), 208-10. http://dx.doi.org/10.3949/ccjm.71.3.208

Haugan, J. A., \& Liaaenjensen, S. (1994). Algal Carotenoids 54. Carotenoids of Brown-Algae (Phaeophyceae). Biochemical Systematics and Ecology, 22(1), 31-41. http://dx.doi.org/10.1016/0305-1978(94)90112-0

He, K. (2009). Fish, long-chain omega-3 polyunsaturated fatty acids and prevention of cardiovascular disease-eat fish or take fish oil supplement? Progress in Cardiovascular Diseases, 52(2), 95-114. http://dx.doi.org/10.1016/j.pcad.2009.06.003

He, K., Song, Y., Daviglus, M. L., et al. (2004). Accumulated evidence on fish consumption and coronary heart disease mortality: a meta-analysis of cohort studies. Circulation, 109(22), 2705-11. http://dx.doi.org/ 10.1161/01.CIR.0000132503.19410.6B

Heo, S. J., Park, E. J., Lee, K. W., et al. (2005). Antioxidant activities of enzymatic extracts from brown seaweeds. Bioresource Technology, 96(14), 1613-23. http://dx.doi.org/10.1016/j.biortech.2004.07.013

Hiratsuka, S., Ishihara, K., Kitagawa, T., et al. (2008). Effect of dietary docosahexaenoic acid connecting 
phospholipids on the lipid peroxidation of the rain in mice. Journal of Nutritional Science and Vitaminology, 54(6), 501-6. http://dx.doi.org/10.3177/jnsv.54.501

Hoshino, Y., Takahashi, Y., Kawarasaki, M., et al. (2008). The suppressive effect of protamine from chum salmon milt on lipid absorption in humans. Nippon Shokuhin Kagaku KogakuKaisi, 55(8), 360-6. http://dx.doi.org/10.3136/nskkk.55.360

Hosokawa, M., Sato, A., Ishigamori, H., et al. (2001). Synergistic effects of highly unsaturated fatty acid-containing phosphatidyl-ethanolamine on differentiation of human leukemia HL-60 cells by dibutyryl cyclic adenosine monophosphate. Japanese Journal of Cancer Research, 92(6), 666-72. http://dx.doi.org/10.1111/j.1349-7006.2001.tb01146.x

Hosomi, R., Fukunaga, K., Arai, H., et al. (2009). Effects of dietary fish protein on serum and liver lipid concentrations in rats and the expression of hepatic genes involved in lipid metabolism. Journal of Agricultural and Food Chemistry, 57(19), 9256-62. http://dx.doi.org/10.1021/jf901954r

Hosomi, R., Fukunaga, K., Arai, H., et al. (2010a). Effect of phospholipid n-3 polyunsaturated fatty acids on rat lipid metabolism. European Journal of Lipid Science and Technology, 112(5), 537-44. http://dx.doi.org/10.1002/ejlt.200900239

Hosomi, R., Fukunaga, K., Arai, H., et al. (2010b). Effect of dietary protamine on lipid metabolism in rats. Nutrition Research and Practice, 4(6), 462-9. http://dx.doi.org/10.4162/nrp.2010.4.6.462

Houweling, A. H., Vanstone, C. A., Trautwein, E. A., et al. (2009). Baseline plasma plant sterol concentrations do not predict changes in serum lipids, C-reactive protein (CRP) and plasma plant sterols following intake of a plant sterol-enriched food. European Journal of Clinical Nutrition, 63(4), 543-51. http://dx.doi.org/10.1038/sj.ejen.1602969

Hu, F. B., Bronner, L., Willett, W. C., et al. (2002). Fish and omega-3 fatty acid intake and risk of coronary heart disease in women. The Journal of the American Medical Association, 287(14), 1815-21. http://dx.doi.org/10.1001/jama.287.14.1815

Huxtable, R. J. (2000). Expanding the circle 1975-1999: sulfur biochemistry and insights on the biological functions of taurine. Advances in Experimental Medicine and Biology, 483(1), 1-25. http://dx.doi.org/10.10 07/0-306-46838-7_1

Huxtable, R. J. (1992). Physiological actions of taurine. Physiol. Rev, 72(1), 101-63.

Hwu, C. M., Hsiung, C. A., Wu, K. D., et al.; SAPPHIRe Study Group. (2008). Diagnosis of insulin resistance in hypertensive patients by the metabolic syndrome: AHA vs. IDF definitions. International Journal of Clinical Practice, 62(9), 1441-6. http://dx.doi.org/10.1111/j.1742-1241.2008.01818.x

Ikeda, K., Kitamura, A., Machida, H., et al. (2003). Effect of Undariapinnatifida (Wakame) on the development of cerebrovascular diseases in stroke-prone spontaneously hypertensive rats. Clinical and Experimental Pharmacology and Physiology, 30(1-2), 44-8. http://dx.doi.org/10.1046/j.1440-1681.2003.03786.x

Ikemoto, A., Ohishi, M., Sato, Y., et al. (2001). Reversibility of n-3 fatty acid deficiency-induced alterations of learning behavior in the rat: level of n-6 fatty acids as another critical factor. The Journal of Lipid Research, 42(10), 1655-63.

Imaizumi, K., Mawatari, K., Murata, M., et al. (1983). The contrasting effect of dietary phosphatidylethanolamine and phosphatidylcholine on serum lipoproteins and liver lipids in rats. Journal of Nutrition, 113(12), 2403-11.

Iwamoto, T., Hosoda, K., Hirano, R., et al. (2000). Inhibition of low-density lipoprotein oxidation by astaxanthin. Journal of Atherosclerosis and Thrombosis, 7(4), 216-22.

Jerlich, A., Fritz, G., Kharrazi, H., et al. (2000). Comparison of HOCl traps with myeloperoxidase inhibitors in prevention of low density lipoprotein oxidation. Biochimicaet Biophysica Acta, 1481(1), 109-18. http://dx.doi.org/10.1016/S0167-4838(00)00112-6

Jimenez-Escrig, A., \& Sanchez-Muniz, F. J. (2000). Dietary fiber from edible seaweeds: chemical structure, physicochemical properties and effects on cholesterol metabolism. Nutrition Research, 20(4), 585-98. http://dx.doi.org/10.1016/S0271-5317(00)00149-4

Jones, P. J., Raeini-Sarjaz, M., Ntanios, F. Y., et al. (2000). Modulation of plasma lipid levels and cholesterol kinetics by phytosterolversus phytostanol esters. The Journal of Lipid Research, 41(5), 697-705. 
Kadekaru, T., Toyama, H., \& Yasumoto, T. (2008). Safety Evaluation of Fucoxanthin purified from Undariapinnatifida, Nippon Shokuhin Kagaku Kogaku Kaishi, 55(6), 304-8. http://dx.doi.org/10.3136/ nskkk.55.304

Kagawa, Y., Nishizawa, M., Suzuki, M., et al. (1982). Eicosapolyenoic acids of serum lipids of Japanese islanders with low incidence of cardiovascular diseases. Journal of Nutritional Science and Vitaminology, 28(4), 441-53. http://dx.doi.org/10.3177/jnsv.28.441

Kanazawa, A. (2001). Sterols in marine invertebrates. Fisheries Science, 67(6), 997-1007. http://dx.doi.org/10.1 046/j.1444-2906.2001.00354.x

Karppi, J., Rissanen, T. H., Nyyssönen, K., et al. (2007). Effects of astaxanthin supplementation on lipid peroxidation. International Journal for Vitamin and Nutrition Research, 77(1), 3-11.

Katan, M. B., Grundy, S. M., Jones, P., et al. (2003). Efficacy and safety of plant stanols and sterols in the management of blood cholesterol levels. Mayo Clinic Proceedings, 78(8), 965-78. http://dx.doi.org/10.4065/78.8.965

Kataoka, H., \& Ohnishi, N. (1986). Occurrence of taurine in plants. Agricultural and Biological Chemistry, 50(7), 1887-88. http://dx.doi.org/10.1271/bbb1961.50.1887

Kawasaki, T., Seki, E., Osajima, K., et al. (2000). Antihypertensive effect of valyl-tyrosine, a short chain peptide derived from sardine muscle hydrolyzate, on mild hypertensive subjects. Journal of Human Hypertension, 14(8), 519-23.

Kim, M. M., Rajapakse, N., \& Kim, S. K. (2009). Antiinflammatory effect of Ishigeokamuraeethanolic extract via inhibition of NF-kappaB transcription factor in RAW 264.7 cells. Phytotherapy Research, 23(5), 628-34. http://dx.doi.org/10.1002/ptr.2674

Krauss, R. M., Eckel, R. H., Howard, B., et al. (2000). AHA Dietary Guidelines: revision 2000: A statement for healthcare professionals from the Nutrition Committee of the American Heart Association. Circulation, 102(18), 2284-99. http://dx.doi.org/10.1161/01.CIR.102.18.2284

Kris-Etherton, P. M., Harris, W. S., \& Appel, L. J.; Nutrition Committee. (2003). Fish consumption, fish oil, omega-3 fatty acids, and cardiovascular disease. Arteriosclerosis, Thrombosis, and Vascular Biology, 23(2), e20-30. http://dx.doi.org/10.1161/01.CIR.0000038493.65177.94

Kris-Etherton, P. M., Harris, W. S., \& Appel, L. J.; American Heart Association. Nutrition Committee. (2002). Fish consumption, fish oil, omega-3 fatty acids, and cardiovascular disease. Circulation, 106(21), 747-57. http://dx.doi.org/10.1161/01.CIR.0000038493.65177.94

Lands, W. E., Libelt, B., Morris, A., et al. (1992). Maintenance of lower proportions of (n-6) eicosanoid precursors in phospholipids of human plasma in response to added dietary (n-3) fatty acids. Biochimicaet Biophysica Acta, 1180(2), 147-62. http://dx.doi.org/10.1016/0925-4439(92)90063-S

Lavie, C. J., Milani, R. V., Mehra, M. R., et al. (2009). Omega-3 polyunsaturated fatty acids and cardiovascular diseases. Journal of the American College of Cardiology, 54(7), 585-94. http://dx.doi.org/10.1016/j.jacc. 2009.02.084

Lesser, M. P. (2006). Oxidative stress in marine environments: biochemistry and physiological ecology. Annual Review of Physiology, 68, 253-78. http://dx.doi.org/10.1146/annurev.physiol.68.040104.110001

Liao, I. C., \& Chao, N. H. (2009). Aquaculture and food crisis: opportunities and constraints. Asia Pacific Journal of Clinical Nutrition, 18(4), 564-9.

Linseisen, J., Welch, A. A., Ocké, M., et al. (2009). Dietary fat intake in the European Prospective Investigation into Cancer and Nutrition: results from the 24-h dietary recalls. European Journal of Clinical Nutrition, 63(Suppl 4), S61-80. http://dx.doi.org/10.1038/ejen.2009.75

Maeda, H., Tsukui, T., Sashima, T., et al. (2008). Seaweed carotenoid, fucoxanthin, as a multi-functional nutrient. Asia Pacific Journal of Clinical Nutrition, 17(Suppl 1), 196-9.

Maeda, H., Hosokawa, M., Sashima, T., et al. (2007). Dietary combination of fucoxanthin and fish oil attenuates the weight gain of white adipose tissue and decreases blood glucose in obese/diabetic KK-Ay mice. Journal of Agricultural and Food Chemistry, 55(19), 7701-6. http://dx.doi.org/10.1021/jf071569n

Maki, K. C., Reeves, M. S., Farmer, M., et al. (2009). Krill oil supplementation increases plasma concentrations of eicosapentaenoic and docosahexaenoic acids in overweight and obese men and women. Nutrition 
Research, 29(9), 609-15. http://dx.doi.org/10.1016/j.nutres.2009.09.004

Malinowski, J. M., \& Gehret, M. M. (2010). Phytosterols for dyslipidemia. American Journal of Health-System Pharmacy, 67(14), 1165-73. http://dx.doi.org/10.2146/ajhp090427

Mannarino, E., Pirro, M., Cortese, C., et al. (2009). Effects of a phytosterol-enriched dairy product on lipids, sterols and 8-isoprostane in hypercholesterolemic patients: a multicenter Italian study. Nutrition, Metabolism \& Cardiovascular Diseases, 19(2), 84-90. http://dx.doi.org/10.1016/j.numecd.2008.03.012

Marangoni, F., \& Poli, A. (2010). Phytosterols and cardiovascular health. Pharmacological Research, 61(3), 193-9. http://dx.doi.org/10.1016/j.phrs.2010.01.001

Marchioli, R., Barzi, F., Bomba, E., et al.; GISSI-Prevenzione Investigators. (2002). Early protection against sudden death by n-3 polyunsaturated fatty acids after myocardial infarction: time-course analysis of the results of the Gruppo Italiano per lo Studio della Sopravvivenza nell'Infarto Miocardico (GISSI)-Prevenzione. Circulation, 105(16), 1897-903. http://dx.doi.org/10.1161/01.CIR.0000014682.14181.F2

Mastellone, I., Polichetti, E., Grès, S., et al. (2000). Dietary soybean phosphatidylcholines lower lipidemia: mechanisms at the levels of intestine, endothelial cell, and hepato-biliary axis. The Journal of Nutritional Biochemistry, 11(9), 461-6.

Matsubara, K., Matsuura, Y., Hori, K., et al. (2000). An anticoagulant proteoglycan from the marine green algae, Codiumpugniformis. Journal of Applied Psychology, 12(1), 9-14. http://dx.doi.org/10.1023/A:1008174115350

Matsushima, Y., Sekine, T., Kondo, Y., et al. (2003). Effects of taurine on serum cholesterol levels and development of atherosclerosis in spontaneously hyperlipidaemic mice. Clinical and Experimental Pharmacology and Physiology. 30(4), 295-9. http://dx.doi.org/10.1046/j.1440-1681.2003.03828.x

McDaniel, M. A., Maier, S. F., \& Einstein, G. O. (2003). Brain-specific" nutrients: a memory cure? Nutrition, 19(11), 957-75. http://dx.doi.org/10.1016/S0899-9007(03)00024-8

McHugh, D. J. (2003). A guide to the seaweed industry. FAO Fisheries Technical Paper 441, 118.

Mendis, E., Rajapakse, N., Byun, H. G., et al. (2005). Investigation of jumbo squid (Dosidicusgigas) skin gelatin peptides for their in vitro antioxidant effects. Life Sciences, 77(17), 2166-78. http://dx.doi.org/10.1016/j.lfs.2005.03.016

Morris, M. C., Evans, D. A., Bienias, J. L., et al. (2003). Consumption of fish and n-3 fatty acids and risk of incident Alzheimer disease. Archives of Neurology, 60(7), 940-6.

Mozaffarian, D., \&Rimm, E. B. (2006). Fish intake, contaminants, and human health: evaluating the risks and the benefits. The Journal of the American Medical Association, 296(15), 1885-99. http://dx.doi.org/10.1001/jama.296.15.1885

Murata, M., Sano, Y., Bannai, S., et al. (2004). Fish protein stimulated the fibrinolysis in rats. Annals of Nutrition and Metabolism, 48(5), 348-56. http://dx.doi.org/10.1159/000081971

Musa-Veloso, K., Poon, T. H., Elliot, J. A., et al. (2011). A comparison of the LDL-cholesterol lowering efficacy of plant stanols and plant sterols over a continuous dose range: results of a meta-analysis of randomized, placebo-controlled trials. Prostaglandins, Leukotrienes and Essential Fatty Acids, 85(1), 9-28. http://dx.doi.org/10.1016/j.plefa.2011.02.001

Nettleton, J. A., \& Katz, R. (2005). n-3 Long-chain polyunsaturated fatty acids in type 2 diabetes: a review. Journal of the American Dietetic Association, 105(3), 428-40. http://dx.doi.org/10.1016/j.jada.2004.11.029

Nkondjock, A., \& Receveur, O. (2003). Fish-seafood consumption, obesity, and risk of type 2 diabetes: an ecological study. Diabetes \& Metabolism, 29(6), 635-42. http://dx.doi.org/DM-12-2003-29-6-1262-3636-10 1019-ART10

Oishi, Y., \& Dohmoto, N. (2009). Alaska pollock protein prevents the accumulation of visceral fat in rats fed a high fat diet. Journal of Nutritional Science and Vitaminology, 55(2), 156-61. http://dx.doi.org/10.3177/jnsv. 55.156

Oomen, C. M., Feskens, E. J., Räsänen, L., et al. (2000). Fish consumption and coronary heart disease mortality in Finland, Italy, and the Netherlands. American Journal of Epidemiology, 151(10), 999-1006.

Osler, M., Helms Andreasen, A., Heitmann, B., et al. (2002). Food intake patterns and risk of coronary heart disease: a prospective cohort study examining the use of traditional scoring techniques. European Journal of Clinical Nutrition, 56(7), 568-74. 
Ouellet, V., Weisnagel, S. J., Marois, J., et al. (2008). Dietary cod protein reduces plasma C-reactive protein in insulin-resistant men and women. Journal of Nutrition, 138(12), 2386-91. http://dx.doi.org/10.3945/jn.108. 092346

Ouellet, V., Marois, J., Weisnagel, S. J., et al. (2007). Dietary cod protein improves insulin sensitivity in insulin-resistant men and women: a randomized controlled trial. Diabetes Care, 30(11), 2816-21. http://dx.doi.org/10.2337/dc07-0273

Patch, C. S., Tapsell, L. C., Williams, P. G., et al. (2006). Plant sterols as dietary adjuvants in the reduction of cardiovascular risk: theory and evidence. Vascular Health and Risk Management, 2(2), 157-62.

Patch, C. S., Tapsell, L. C., \& Williams, P. G. (2005). Plant sterol/stanol prescription is an effective treatment strategy for managing hypercholesterolemia in outpatient clinical practice. Journal of the American Dietetic Association, 105(1), 46-52. http://dx.doi.org/10.1016/j.jada.2004.10.024

Patel, P. S., Sharp, S. J., Luben, R. N., et al. (2009). Association between type of dietary fish and seafood intake and the risk of incident type 2 diabetes: the European prospective investigation of cancer (EPIC)-Norfolk cohort study. Diabetes Care, 32(10), 1857-63. http://dx.doi.org/10.2337/dc09-0116

Pengzhan, Y., Ning, L., Xiguang, L., et al. (2003). Antihyperlipidemic effects of different molecular weight sulfated polysaccharides from Ulvapertusa (Chlorophyta). Pharmacological Research, 48(6), 543-9. $\mathrm{http}: / / \mathrm{dx}$.doi.org/10.1016/S1043-6618(03)00215-9

Pereira, M. A., O'Reilly, E., Augustsson, K., et al. (2004). Dietary fiber and risk of coronary heart disease: a pooled analysis of cohort studies. Archives of Internal Medicine, 164(4), 370-6.

Peyron-Caso, E., Fluteau-Nadler, S., Kabir, M., et al. (2002). Regulation of glucose transport and transporter 4 (GLUT-4) in muscle and adipocytes of sucrose-fed rats: effects of N-3 poly- and monounsaturated fatty acids. Hormone and Metabolic Research, 34(7), 360-6. http://dx.doi.org/10.1055/s-2002-33467

Plaza, M., Herrero, M., Cifuentes, A., et al. (2009). Innovative natural functional ingredients from microalgae. Journal of Agricultural and Food Chemistry, 57(16), 7159-70. http://dx.doi.org/10.1021/jf901070g

Ramel, A., Martinez, J. A., Kiely, M., et al. (2010). Effects of weight loss and seafood consumption on inflammation parameters in young, overweight and obese European men and women during 8 weeks of energy restriction. European Journal of Clinical Nutrition, 64(9), 987-93. http://dx.doi.org/10.1038/ejen. 2010.99

Ramel, A., Martinéz, A., Kiely, M., et al. (2008). Beneficial effects of long-chain n-3 fatty acids included in an energy-restricted diet on insulin resistance in overweight and obese European young adults. Diabetologia, 51(7), 1261-8. http://dx.doi.org/10.1007/s00125-008-1035-7

Rasmussen, H. E., Blobaum, K. R., Jesch, E. D., et al. (2009). Hypocholesterolemic effect of Nostoc commune var. Sphaeroides Kützing, an edible blue-green algae. European Journal of Nutrition, 48(7), 387-394. http://dx.doi.org/10.1007/s00394-009-0025-y

Robic, A., Gaillard, C., Sassi, J. F., et al. (2009). Ultrastructure of ulvan: a polysaccharide from green seaweeds. Biopolymers, 91(8), 652-64. http://dx.doi.org/10.1002/bip.21195

Robinson, J. G., Ijioma, N., \& Harris, W. (2010). Omega-3 fatty acids and cognitive function in women. Women's health (London, England), 6(1), 119-34. http://dx.doi.org/10.2217/whe.09.75

Rosell, M., Wesley, A. M., Rydin, K., et al.; EIRA study group. (2009). Dietary fish and fish oil and the risk of rheumatoid arthritis. Epidemiology, 20(6), 896-901. http://dx.doi.org/10.1097/EDE.0b013e3181b5f0ce

Rudkowska, I. (2010). Fish oils for cardiovascular disease: Impact on diabetes. Maturitas, 67(1), 25-8. http://dx.doi.org/10.1016/j.maturitas.2010.04.012

Ryan, A. S., Astwood, J. D., Gautier, S., et al. (2010). Effects of long-chain polyunsaturated fatty acid supplementation on neurodevelopment in childhood: a review of human studies. Prostaglandins, Leukotrienes and Essential Fatty Acids, 82(4-6), 305-14. http://dx.doi.org/10.1016/j.plefa.2010.02.007

Schaffer, S. W., Jong, C. J., Ramila, K. C., et al. (2010). Physiological roles of taurine in heart and muscle. Journal of Biomedical Science, 17(Suppl 1), S2. http://dx.doi.org/10.1186/1423-0127-17-S1-S2

Schuller-Levis, G. B., \& Park, E. (2004). Taurine and its chloramine: modulators of immunity. Neurochemical Research, 29(1), 117-26. http://dx.doi.org/10.1023/B:NERE.0000010440.37629.17

Shahidi, F. (1998). Functional seafood lipids and proteins. In Mazza G., (Eds.). Functional Foods (pp.381-98), 
Pennsylvania: Technomic publication.

Shahidi, F. (2011). Omega-3 Fatty Acids in Health and Disease. In Hernandez, E., \& Hosokawa, M., (Eds.). Omega-3 Oils Applications in Functional Foods (pp.1-30), Illinois: AOCS Press.

Shirouchi, B., Nagao, K., Inoue, N., et al. (2007). Effect of dietary omega 3 phosphatidylcholine on obesity-related disorders in obese Otsuka Long-Evans Tokushima fatty rats. Journal of Agricultural and Food Chemistry, 55(17), 7170-6. http://dx.doi.org/10.1021/jf071225x

Shukla, A., Bettzieche, A., Hirche, F., et al. (2006). Dietary fish protein alters blood lipid concentrations and hepatic genes involved in cholesterol homeostasis in the rat model. British Journal of Nutrition, 96(4), 674-82. http://dx.doi.org/10.1079/BJN20061895

Singh, R. B., Niaz, M. A., Sharma, J. P., et al. (1997). Randomized, double-blind, placebo-controlled trial of fish oil and mustard oil in patients with suspected acute myocardial infarction: the Indian experiment of infarct survival-4. Cardiovascular Drugs and Therapy, 11(3), 485-91. http://dx.doi.org/10.1023/A:1007757724505

Stenson, W. F., Cort, D., Rodgers, J., et al. (1992). Dietary supplementation with fish oil in ulcerative colitis. Annals of Internal Medicine, 116(8), 609-14.

Story, M., Kaphingst, K. M., Robinson-O'Brien, R., et al. (2008). Creating healthy food and eating environments: policy and environmental approaches. Annual Review of Public Health, 29, 253-72. http://dx.doi.org/10.114 6/annurev.publhealth.29.020907.090926

Szymanski, K. M., Wheeler, D. C., \& Mucci, L. A. (2010). Fish consumption and prostate cancer risk: a review and meta-analysis. The American Journal of Clinical Nutrition, 92(5), 1223-33. http://dx.doi.org/10.3945/ ajcn.2010.29530

Terry, P., Lichtenstein, P., Feychting, M., et al. (2001). Fatty fish consumption and risk of prostate cancer. Lancet, 357(9270), 1764-6. http://dx.doi.org/10.1016/S0140-6736(00)04889-3

Thies, F., Garry, J. M., Yaqoob, P., et al. (2003). Association of n-3 polyunsaturated fatty acids with stability of atherosclerotic plaques: a randomised controlled trial. Lancet, 361(9356), 477-85. http://dx.doi.org/10.1016 /S0140-6736(03)12468-3

Thompson, G. R., \& Grundy, S. M. (2005). History and development of plant sterol and stanol esters for cholesterol-lowering purposes. American Journal of Cardiology, 96(1A), 3D-9D. http://dx.doi.org/10.1016/j. amjcard.2005.03.013

Tincu, J. A., \& Taylor, S. W., (2004). Antimicrobial peptides from marine invertebrates. Antimicrobial Agents and Chemotherapy. 48(10), 3645-54. http://dx.doi.org/10.1128/AAC.48.10.3645-3654.2004

Toshima, H. (1994). Coronary artery disease trends in Japan. Japanese Circulation Journal, 58(3), 66-72.

Tsuji, K., \& Yano, S. (1984). Taurine/cholesterol ratio of well-consumed animal foods. Sulfur Amino Acids, 7, 249-55.

Tsujita, T., Matsuura, Y., \& Okuda, H. (1996). Studies on the inhibition of pancreatic and carboxylester lipases by protamine. The Journal of Lipid Research, 37(7), 1481-7.

US Food and Drug Administration, (2004). What you need to know about mercury in fish and shellfish. Retrieved from http://www.fda.gov/food/foodsafety/product-specificinformation/seafood/foodbornepathog enscontaminants/methylmercury/ucm 115662.htm (February 29, 2012)

Volker, D., Fitzgerald, P., Major, G., et al. (2000). Efficacy of fish oil concentrate in the treatment of rheumatoid arthritis. The Journal of Rheumatology, 27(10), 2343-6.

vonSchacky, C., Angerer, P., Kothny, W., et al. (1999). The effect of dietary omega-3 fatty acids on coronary Atherosclerosis. A randomized, double-blind, placebo-controlled trial. Annals of Internal Medicine, 130(7), 554-62.

Walton, A. J., Snaith, M. L., Locniskar, M., et al. (1991). Dietary fish oil and the severity of symptoms in patients with systemic lupus erythematosus. Annals of the Rheumatic Diseases, 50(7), 463-6.

Wang, L., Xue, C., Wang, Y., et al. (2011). Extraction of proteins with low fluoride level from Antarctic krill (Euphausiasuperba) and their composition analysis. Journal of Agricultural and Food Chemistry, 59(11), 6108-12. http://dx.doi.org/10.1021/jf201009t

Wergedahl, H., Gudbrandsen, O. A., Røst, T. H., et al. (2009). Combination of fish oil and fish protein hydrolysate reduces the plasma cholesterol level with a concurrent increase in hepatic cholesterol level in 
high-fat-fed Wistar rats. Nutrition, 25(1), 98-104. http://dx.doi.org/10.1016/j.nut.2008.07.005

Wergedahl, H., Liaset, B., Gudbrandsen, O. A., et al. (2004). Fish protein hydrolysate reduces plasma total cholesterol, increases the proportion of HDL cholesterol, and lowers acyl-CoA: cholesterolacyltransferase activity in liver of Zucker rats. Journal of Nutrition, 134(6), 1320-7.

Wijendran, V., Huang, M. C., Diau, G. Y., et al. (2002). Efficacy of dietary arachidonic acid provided as triglyceride or phospholipid as substrates for brain arachidonic acid accretion in baboon neonates. Pediatric Research, 51(3), 265-72. http://dx.doi.org/10.1203/00006450-200203000-00002

Wójcik, O. P., Koenig, K. L., Zeleniuch-Jacquotte, A., et al. (2010). The potential protective effects of taurine on coronary heart disease. Atherosclerosis, 208(1), 19-25. http://dx.doi.org/10.1016/j.atherosclerosis.2009.06. 002

Woo, M. N., Jeon, S. M., Kim, H. J., et al. (2010). Fucoxanthin supplementation improves plasma and hepatic lipid metabolism and blood glucose concentration in high-fat fed C57BL/6N mice. Chemico-Biological Interactions, 186(3), 316-22. http://dx.doi.org/10.1016/j.cbi.2010.05.006

Yaktine, A. L., \& Nesheim, M. C. (2007). Seafood choices-balancing benefits and risks, Washington: The National Academies Press (Chapter 4).

Yoshida, H., Yanai, H., Ito, K., et al. (2010). Administration of natural astaxanthin increases serum HDL-cholesterol and adiponectin in subjects with mild hyperlipidemia. Atherosclerosis, 209(2), 520-3. http://dx.doi.org/10.1016/j.atherosclerosis.2009.10.012

Yoshizawa, K., Rimm, E. B., Morris, J. S., et al. (2002). Mercury and the risk of coronary heart disease in men. The New England Journal of Medicine, 347(22), 1755-60.

Zhang, J., Sasaki, S., Amano, K., et al. (1999). Fish consumption and mortality from all causes, ischemic heart disease, and stroke: an ecological study. Preventive Medicine, 28(5), 520-9. http://dx.doi.org/10.1006/pmed. 1998.0472

Zhang, M., Bi, L. F., Fang, J. H., et al. (2004). Beneficial effects of taurine on serum lipids in overweight or obese non-diabetic subjects. Amino Acids, 26(3), 267-71. http://dx.doi.org/10.1007/s00726-003-0059-z

Zhang, X., \& Beynen, A. C. (1993). Influence of dietary fish proteins on plasma and liver cholesterol concentrations in rats. British Journal of Nutrition, 69(3), 767-77. http://dx.doi.org/10.1079/BJN19930077 